\title{
MOLECULAR IDENTIFICATION OF ARBUSCULAR MYCORRHIZAL FUNGI IN ROOTS: PERSPECTIVES AND PROBLEMS
}

\author{
Dirk Redecker ${ }^{1,2)}$, Isabelle Hijri ${ }^{1)}$ \& Andres Wiemken ${ }^{1)}$ \\ Botanisches Institut der Universität Basel, Hebelstr. 1, CH-4056 Basel, Switzerland; 2) Corresponding author: \\ fax+41612672330,e-mail dirk.redecker@unibas.ch
}

\begin{abstract}
Molecular identification methods are about to revolutionize studies on ecology of arbuscular mycorrhiza. These techniques offer the unique opportunity to investigate communities of arbuscular mycorrhizal fungi (AMF) within roots. Recent technical advances are reviewed, discussing their drawbacks and advantages. An experimental approach to analyze AMF communities within roots using a molecular identification method is presented. Sample results from the analysis of trap cultures from a current project are shown.
\end{abstract}

Keywords: Arbuscular mycorrhiza, Internal transcribed spacers, Mycorrhizal ecology, Polymerase chain reaction, rDNA

\section{WHY MOLECULAR IDENTIFICATION?}

Arbuscular mycorrhizal fungi (AMF) have traditionally been identified by the morphology of their spores. In the absence of spores, the intraradical structures at best allow identification to the family level (MERRYWEATHER \& FITTER 1998). Moreover, several lineages of AMF have been discovered that do not stain at all within the roots, or only very weakly using the standard dyes (MORTON \& REDECKER 2001).

Spore production is highly dependent on physiological parameters of the AMF and on environmental conditions. Under certain conditions or during certain seasons of the year, some AMF may produce many spores and therefore appear to be dominant root colonizers, whereas under different conditions, they may not sporulate at all. Furthermore, the dynamics of spore production versus root colonization may differ among species (BEVER et al. 1996). Non-sporulating species may not be detected at all whereas prolific spore-producers dominate our views of AMF ecology.

A similar discrepancy was reported for ectomycorrhizal fungi. Using molecular methods, GARDES \& BRUNS (1996) showed that the ectomycorrhizal fungus Suillus pungens occupies only $4 \%$ of ectomycorrhizal root tips in a coastal California forest, although it produced more fruit bodies than any other ectomycorrhizal fungus at the study site. On the other hand, fruit bodies of dominant root colonizers like Russula amoenolens were scarcely found.

Another limitation of morphological identification is the fact that field-collected spores are often parasitized or degraded and therefore unidentifiable. This problem can be circumvented by setting up "AMF trap cultures": soil samples from the field site are brought into contact with suitable plant hosts of AMF under controlled conditions in order to propagate the species 
occurring at the field site and to obtain fresh spores of all developmental stages. However, the plant species used in the trap cultures may have an influence on which AMF are detected (JANSA et al. 2002).

However, even the identification of healthy spores may pose problems, because morphological characters are scarce in some AMF. For example, Glomus and Paraglomus cannot be discerned by spore morphology but are distantly related. Even after the separation of the genus from Paraglomus (MORTON \& REDECKER 2001), the genus Glomus is still polyphyletic, because it comprises two independent lineages according to molecular criteria (SCHWARZOTT et al. 2001). Dimorphic AMF species (e.g. Archaeospora leptoticha, Glomus dimorphicum) can cause further confusions in morphological identification. Nevertheless, it is still common to quantify the occurrence of AMF by counting spores from field sites, notwithstanding the problems that are known with this approach.

Molecular identification techniques have the potential to revolutionize AMF ecology because they offer the opportunity to identify AMF in any given root sample without the need for spores. There is also the potential to identify hyphae in the soil, but here the necessary techniques have not been developed yet satisfactorily.

\section{MOLECULAR IDENTIFICATION METHODS}

Almost all identification systems for AMF are based on the ribosomal DNA. The genes of this genome region are available in high copy number and possess highly-conserved as well as variable sectors, which allows to distinguish taxa at many different levels. Molecules other than DNA, e.g. fatty acids (GRAHAM et al. 1995) or isozymes (DODD et al. 1996) have been analyzed, but are not widely used. DNA has the advantage that there are no problems with gene expression because genotypes are analyzed directly. Furthermore, phylogenetic analyses based on DNA sequences allow direct conclusions about the evolutionary history and the relationship of the taxa in question.

The biggest road block on the path to develop DNA-based molecular identification techniques was removed by the introduction of the polymerase chain reaction (PCR) (SAIKI et al. 1988). Only since this technique became available, the analysis of small amounts of DNA from organisms that cannot be cultured axenically, such as AMF, has become feasible.

The majority of authors have targeted parts of the ribosomal genes for molecular identification. In only a few studies, other regions were used, e.g, a RAPD fragment of unknown function (LANFRANCO et al. 1995). The first three $18 \mathrm{~S}$ small subunit (SSU) sequences from ribosomal DNA of these fungi were determined by SIMON et al. (1992). Based on these data, the authors designed a specific PCR primer for AMF, VANS1. Later, other group-specific primers for lineages of AMF were added (SIMON et al. 1993). The VANS1 primer was used in some studies (CLAPP et al. 1995, DI BONITO et al. 1995), but when more SSU sequences were available, it became clear that the VANS1 priming site is not well-conserved in all groups of the AMF (CLAPP et al. 1999, REDECKER et al. 2000, SCHÜBLER et al. 2001).

Using the primers designed by Simon et al. and a subtraction-hybridization technique, CLAPP et al. (1999) studied a field population of AMF and found a clear discrepancy by some Glomus spp. between strong root colonization and the absence of the respective spores. 
Other authors used the 28S large ribosomal subunit (LSU). VAN TUINEN et al. (1998) designed several specific primers targeting the highly variable D2 region of the LSU, each for a different AMF species. KJøLLER \& ROSENDAHL (2001) used a primer specific for a Glomus subgroup (comprising $G$. mosseae and $G$. intraradices) for this region to study field populations of AMF in pea roots.

HELGASON et al. (1998) used a single primer (AM1) targeted at a region of the SSU and amplifying most, but not all glomalean fungi, to analyze AMF communities in roots from agricultural sites and a semi-natural woodland. Interestingly, these authors showed that the AMF community in the agricultural sites was reduced to almost a single AMF sequence type, corresponding to Glomus mosseae.

REDECKER (2000) designed group-specific primers for five major phylogenetic lineages of AMF to amplify the highly variable ITS. This system, which was recently used to identify the fungal symbionts of mycoheterotrophic plants (BIDARTONDO et al. 2002), will be presented in more detail below.

\section{POSSIBLE OBSTACLES FOR MOLECULAR IDENTIFICATION OF AMF}

To highlight problems encountered when studying communities of AMF with molecular methods, it is useful to compare the methods to those in molecular studies of ectomycorrhizal fungi. Molecular identification of ectomycorrhizal fungi was established much earlier than AMF (GARDES et al. 1991, GARDES \& BRUNS 1993, 1996).

The two biological systems are different in some key aspects that are listed in Table 1 . Ectomycorrhizal root tips are usually (but not always) colonized by one sole fungus and the tips can be easily separated. In these tips, other fungi are usually not found in quantities similar to the ectomycorrhizal fungus, therefore a fungal-specific primer to exclude plant DNA is sufficient. The number of root tips occupied by one fungal species or their dry weight gives a handy measure of the relative contribution of each fungal species to the ectomycorrhizal root community. Some ectomycorrhizal fungi can be grown axenically and are therefore generally easier accessible to molecular biological methods.

Fungal tissue is embedded deeply within the roots in arbuscular mycorrhiza and therefore DNA extraction can be more of a problem. AMF-specific primers are required because otherwise, numerous pathogenic and saprophytic fungi will be co-detected. To design one primer for all glomalean fungi excluding plants and other fungi has proven to be difficult. The problem can be avoided by using group-specific primers. One piece of root can be colonized by different AMF, and the multiple component colonizers have to be separated by cloning the PCR products (CLAPP et al. 1995, VAN TUINEN et al. 1998, HELGASON et al. 1999). To quantify root colonization by AMF, the relative numbers of clones have been used as a measure (HELGASON et al. 1999). Quantitative PCR has also been employed in one study of Glomus mosseae (EDWARDS et al. 1997), although under carefully-controlled laboratory conditions.

Ribosomal DNA (rDNA) is highly polymorphic in single spores of AMF. This is in contrast to many other fungi, in which variable rDNA sequences (e.g. the internal transcribed spacers, ITS) are often identical within a species. Exceptions however, have been reported in ectomycorrhizal fungi (HORTON 2002), other fungi (O'DONNELL 1992) as well as plants 
Table 1. Differences in biological systems necessitate different approaches for molecular identification of ectomycorrhizal fungi and AMF.

\begin{tabular}{|c|c|c|}
\hline & Ectomycorrhiza & Arbuscular mycorrhiza \\
\hline Fungal tissue & outside and inside root & inside of root \\
\hline Ratio fungus/plant tissue & high & low \\
\hline Number of colonization & usually one fungus per root tip & multiple colonizations not separated \\
\hline Primers & fungal specific primer can be used & AMF-specific primer(s) required \\
\hline rDNA & usually monomorphic in species & highly polymorphic in single spores \\
\hline Quantification & $\begin{array}{l}\text { number or dry weight of } \\
\text { root tips }\end{array}$ & $\begin{array}{l}\text { number of clones from mixed PCRs, } \\
\text { multiple PCRs, quantitative PCR }\end{array}$ \\
\hline
\end{tabular}

(BUCKLER et al. 1997). On the other hand, identical ITS do not automatically mean that two fungi are conspecific, only that they are closely related.

A single genetic locus (e.g. rDNA) does not give a clear cutoff between intra-species genetic variation and among-species variation. This problem was addressed by establishing species concepts based on gene genealogy. In a biological species concept, a species is a unit of interbreeding individuals. In some fungi, mating tests have been used to diagnose species (ANDERSON \& ULLRICH 1979), but this technique is not applicable to many fungi, because they do not mate under laboratory conditions or cannot be cultivated at all, like AMF. Molecular genetic methods have allowed scientists to obtain genetic markers for many fungi, even those that cannot be cultivated. Therefore, a concept termed genealogical concordance phylogenetic species recognition (GCPSR) was devised which detects the gene flow caused by interbreeding. according to this concept, different species are characterized by genetic isolation (TAYLOR et al. 2000).

So far, similar concepts have been applied to a wide range of Asco- and Basidiomycetes, and in most cases, at least two cryptic species were detected within each morphologically-defined species (e.g. KOUFOPANOU et al. 1997). However, it is questionable whether phylogenetically-based species concepts like these are applicable in AMF. It was recently reported that nuclei in the coenocytic mycelium of AMF are genetically different, and that AMF reproduce mainly clonally (asexually) (KUHN et al. 2001). GCPSR is not applicable to truly clonal lineages, because each of these is genetically isolated from other lineages and would therefore represent a species.

It was hypothesized that anastomosis between AMF mycelia could account for some genetic exchange. However, although anastomoses between hyphae of the same mycelium and among descendants of the same isolate appear to be common (GIOVANNETTI et al. 1999), there is currently no evidence that anastomoses occur between individuals from different isolates and may therefore be a substitute for mating.

A recent study on Glomus coronatum (CLAPP et al. 2001) suggests that AMF spores may contain ribosomal genes from different morphospecies. However, in most cases multispore isolates were used and the genetic analyses were conducted with DNA extracts from large numbers of spores. Therefore it cannot completely be ruled out that these results reflect the heterogeneity of the spore material rather than mixed populations of nuclei. The same group reported that single spores of Entrophospora infrequens contain rDNA genes from different 
species of Glomus and the Gigasporaceae, separately or even in combination (RODRIGUEZ et al. 2001). E. infrequens has always presented an enigma. There is only one report of its pure culture (SIEVERDING \& TORO 1985). E. infrequens does not belong to the typical AMF, it may not even be mycorrhizal at all. Therefore it is not clear how relevant these findings are for an understanding of the biology of AMF.

Clearly, more work needs to be done to elucidate how the supposed heterogeneity of nuclei is maintained in the mycelium, whether genetic material is exchanged between morphospecies and, should this be the case, how morphospecies can arise and continue to exist under these conditions.

The lack of a clear species concept and the polymorphism of currently-used marker genes renders it problematic to clearly define AMF species by molecular methods. For example, the same ITS sequence is rarely recovered twice from a single spore (LANFRANCO et al. 1999, ANTONIOLLI et al. 2000). Even when sequences both from spores and roots at a given site are available, there is usually no simple match possible between them. Therefore, molecular studies of AMF communities primarily identify sequence groups, not species. These groups may eventually be found to correspond to morphospecies or groups of them.

When phylogenetic analyses show that a sequence falls within a clade of sequences from a defined morphospecies, it can be identified rather safely. This is only possible in the few cases where multiple DNA sequence clones are available from isolates of a defined morphospecies. The picture is, however, obscured by misidentified and otherwise questionable sequences that are accumulating in the databases. While the widely known Ascomycete sequences from Scutellospora castanea (REDECKER et al. 1999) have been corrected in the meantime, ITS sequences of Entrophospora contigua and Acaulospora lacunosa have been published which have closer similarity to Basidiomycetes than to other members of Acaulosporaceae.

\section{AN EXAMPLE: MOLECULAR IDENTIFICATION OF ROOT-COLONIZING AMF IN SAMPLES FROM TRAP CULTURES}

To illustrate advantages and possible problems of molecular identification of AMF, we present an example of molecular identification of AMF within roots from our current effort to characterize AMF populations in a range of field sites comprising intensive agriculture, organic farming and semi-natural grasslands (for methods see Appendix). Trap cultures with three different host plants (Lolium perenne, Plantago lanceolata, Trifolium pratense) have been set up with soils from the field sites. Spore populations from these trap cultures have been characterized by morphological methods. An inverse correlation between the level of intensity of agriculture and the morphospecies number was found (OEHL et al. 2003). We have now begun to study the AMF within the roots produced in the trap cultures by molecular methods, and to compare them to AMF from roots obtained directly from the respective field sites. Due to host preference (HELGASON et al. 2002, BIDARTONDO et al. 2002) or environmental factors, not all fungi present in the original field soil may colonize the respective trap plants. This may influence the set of AMF species recovered from the trap cultures (JANSA et al. 2002). However, it should be kept in mind that by trap culturing and direct analysis of field roots two potentially different AMF populations are measured, namely 


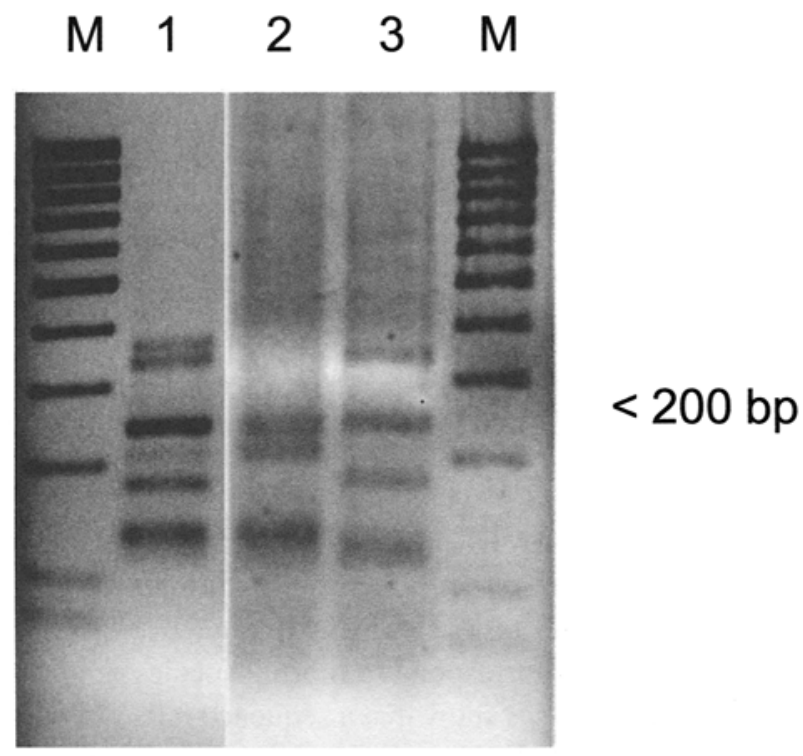

Fig. 1. Screening of PCR products and cloned PCR products by RFLP analysis. Depicted are restriction patterns of PCR products (primers GLOM1310/ITS4i) digested with the restriction enzyme Hinfl. M-100 base pair ladder ( $80 \mathrm{bp}, 100-1000 \mathrm{bp}$ ). Lane 1: Restriction pattern from PCR product from a root sample. Lane 2 and 3: Restriction patterns of clones 49-3 and 49-4 obtained from the PCR product in lane 1.

the inoculum in the field soil and the fungi currently active within the roots. Therefore, the two methods complement each other in the characterization of a field site.

\section{PCR and restriction analysis}

From a trap culture root sample, DNA fragments with an approximate length of 1000 base pairs were obtained by PCR with the specific primer pairs GLOM1310/ITS4i and ARCH1311/ITS4i, respectively. In order to identify the respective fungi, these PCR products were then characterized by restriction fragment length polymorphism (RFLP), cloned and sequenced. The target group of the GLOM1310 primer is a subgroup of the genus Glomus (REDECKER 2000), named Glomus group A by SCHÜßLER et al. (2001). The ARCH1311 primer amplifies from members of Archaeosporaceae and Paraglomeraceae (REDECKER 2000).

The RFLP patterns offer a convenient way to minimize time-consuming and costly DNA sequencing. Once a RFLP pattern has been recorded, it can be used to match new sequences without the need to sequence them. In our experience, two RFLP assays with the enzymes $M b o \mathrm{I}$ and Hinfl are sufficient to distinguish many morphospecies of glomalean fungi we tested, with the exception of the Gigasporaceae.

As a specific example, the RFLP pattern of the GLOM1310 PCR amplification product is shown in Fig. 1, lane 1. Typically, the RFLP pattern is composed of several components and 


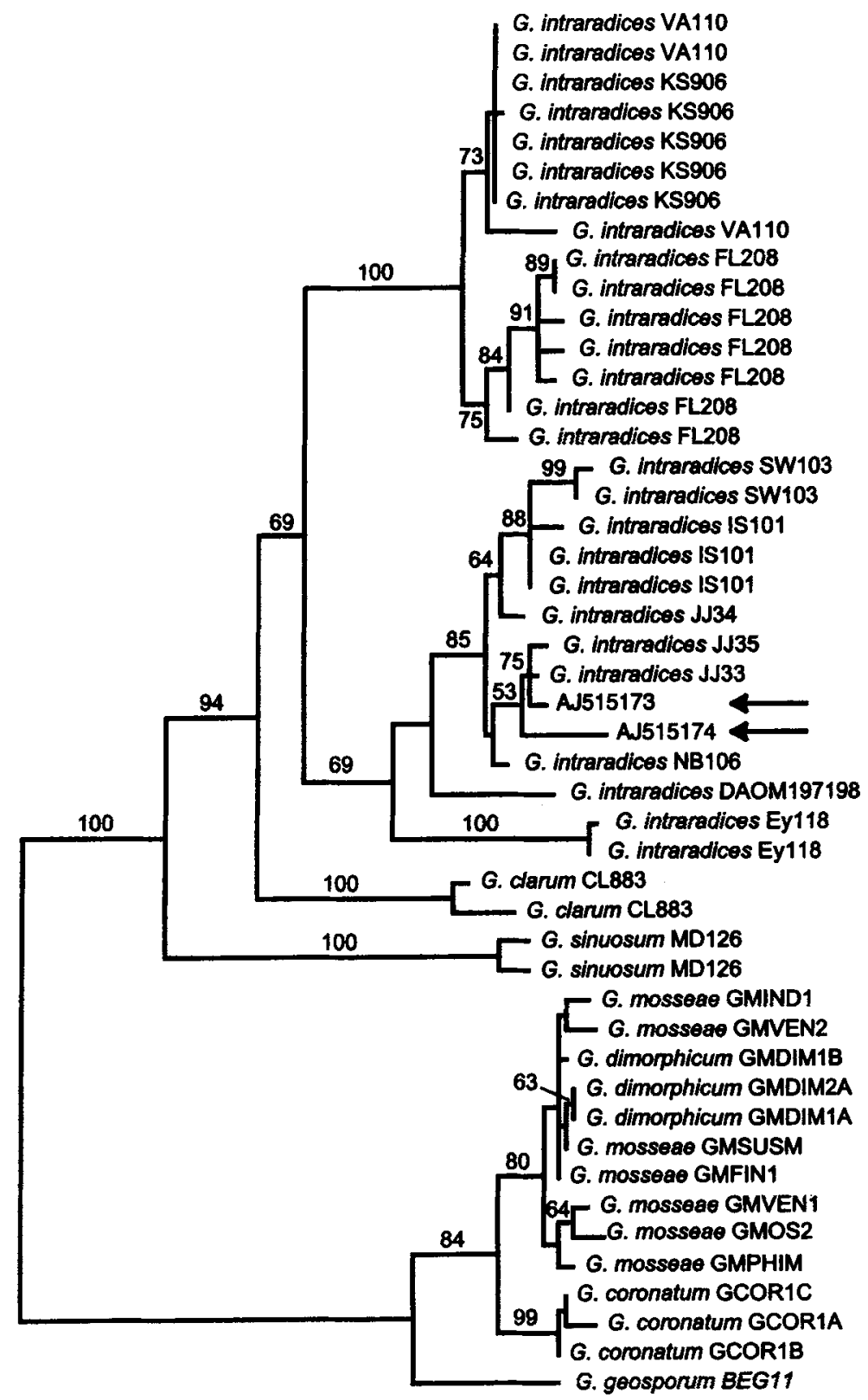

-5 changes

Fig. 2. Phylogenetic tree of Glomus group A from sequences of the 5.8S subunit and ITS2. Sequences with arrows correspond to the clones 49-3 and 49-4 in Fig. 1 (lanes 2 and 3). The tree is one of 500 equally parsimonious trees obtained by a heuristic search using PAUP*4b10 (SWOFFORD 2002). The number of trees retained was limited to 500 . The major branches are present in all of those trees. The tree was rooted by midpoint rooting. Numbers above the nodes indicate bootstrap values from 100 replicates, only values above $60 \%$ are shown. Arrows indicate the new sequences to be tested. 


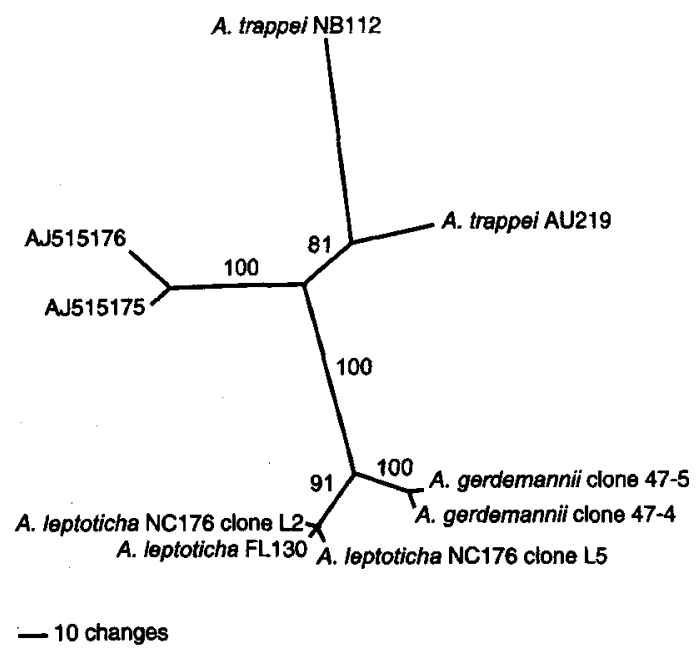

Fig. 3. Phylogenetic tree of Archaeospora, using ITS sequences. The unrooted tree is one of three equally parsimonious trees obtained by a heuristic search PAUP*4b10 (SWOFFORD 2002). Numbers denote bootstrap values from 100 replicates. Note that the ITS of $A$. trappei and the $A$. gerdemannii/A. leptoticha group cannot be easily aligned to each other. The tree is therefore mainly intended to show the genetic distances within the groups.

the total of the fragment sizes is larger than the original PCR product. The PCR product was cloned to separate the components leading to this complex pattern and to allow sequencing. The cloned PCR fragments were then screened by RFLP to identify possible different sequence types. We used the restriction enzymes $\operatorname{Hinfl}$ (Fig. 1) and $M$ BoI (not shown). The two RFLP types we found are presented in Fig. 1. Other clones we screened had one of the two patterns shown.

At this point of the procedure, the RFLP patterns are usually compared to a pattern library, and if the respective pattern was sequenced before, the respective clone can be linked directly to this sequence type without actually sequencing it.

In our example, the clones in Fig. 1, lane 2 and 3 were sequenced.

\section{Phylogenetic matching of ITS sequences}

The ITS sequences of the two clones with different RFLP patterns were analyzed by phylogenetic methods. The resulting phylogenetic tree is shown in in Fig. 2. The dataset contained the new ITS sequences to be tested (arrows) as well as database sequences from members of Glomus group A, comprising G. intraradices and $G$. mosseae. Only the $5.8 \mathrm{~S}$ subunit and the second part of the ITS (ITS2) were used because ITS1 was too difficult to align. Generally, aligning ITS is problematic because of numerous insertions and deletions.

Database sequences labeled "Glomus intraradices" fell into two distinct clusters but formed a monophyletic group. Sequences from the same isolate mostly grouped together.

The sequences AJ515173 and AJ515174 were nested within a cluster of sequences of Glomus intraradices (Fig. 2). The glomalean fungus in the roots of that trap culture could therefore tentatively be identified as belonging to this species. 
Another example for phylogenetic analysis of root-derived ITS sequences is shown in Fig. 3. Two sequences amplified with the ARCH1311/ITS4i primers showed a close relationship to Archaeospora trappei. The two sequences AJ515175 and AJ515176 were obtained from the same sample of colonized roots as the Glomus sequences discussed above. At present, the number of sequences from spores of $A$. trappei is too small to allow an unequivocal statement that the two unknown sequences fall within the range of $A$. trappei isolates. Therefore we tentatively identify these two sequences as "Archaeospora sp.". A possible solution will be to search for the corresponding spores.

\section{CONCLUSION}

Our examples illustrate some typical problems that are encountered with molecular identification of AMF by ribosomal sequences. Nevertheless, this experimental approach, in combination with the classic morphological analyses of spores, is highly promising and should provide a workable strategy to better characterize AMF communities within roots.

Acknowledgments: We would like to thank Thomas Boller, Stefanie Possekel and Kurt Ineichen for suggestions on the manuscript. We also would like to thank Fritz Oehl for providing a root sample from a trap culture he set up.

\section{REFERENCES}

ANDERSON J.B. \& ULLRICH R.C. (1979): Biological species of Armillaria mellea in North America. Mycologia 71: $402-414$.

ANTONIOLLI Z.I., SCHACHTMAN D.P., OPHEL K.K. \& SMITH S.E. (2000): Variation in rDNA ITS sequences in Glomus mosseae and Gigaspora margarita spores from a permanent pasture. Mycol. Res. 104: 708-715.

BEVER J.D., MORTON J.B., ANTONOVICS J. \& SCHULTZ P.A. (1996): Host-dependent sporulation and species diversity of arbuscular mycorrhizal fungi in a mown grassland. $J$. Ecol. 84: 71-82.

BIDARTONDO M.I., REDECKER D., HIJRI I., WIEMKEN A., BRUNS T.D., DOMINGUEZ L., SÉRSIC A., LEAKE J.R. \& READ D.J. (2002): Epiparasitic plants specialized on arbuscular mycorrhizal fungi. Nature 419: $389-393$.

BUCKLER E.S.I., IPPOLITO A. \& HOLTSFORD T.P. (1997): The evolution of ribosomal DNA: Divergent paralogues and phylogenetic implications. Genetics 145: 821-832.

CLAPP J.P., FITTER A.H. \& YOUNG J.P.W. (1999): Ribosomal small subunit sequence variation within spores of an arbuscular mycorrhizal fungus, Scutellospora sp. Molec. Ecol. 8: 915-921.

CLAPP J.P., RODRIGUEZ A. \& DODD J.C. (2001): Inter- and intra-isolate rRNA large subunit variation in Glomus coronatum spores. New Phytol. 149: 539-554.

CLAPP J.P., YOUNG J.P.W., MERRYWEATHER J.W. \& FiTTER A.H. (1995): Diversity of fungal symbionts in arbuscular mycorrhizas from a natural community. New Phytol. 130: 259-265.

Di BONITO R., ELLIOTT M.L. \& DES JARDIN E.A. (1995): Detection of an arbuscular mycorrhizal fungus in roots of different plant species with the PCR. Appl. Environm. Microbiol. 61: 2809-2810.

DODD J.C., Rosendahl S., GIOVANNETTI M., BROOME A., LANFRANCO L. \& WALKER C. (1996): Inter- and intraspecific variation within the morphologically-similar arbuscular mycorrhizal fungi Glomus mosseae and Glomus coronatum. New Phytol. 133: 113-122.

EDWARDS S.G., FITTER A.H. \& YOUNG J.P.W. (1997): Quantification of an arbuscular mycorrhizal fungus, Glomus mosseae, within plant roots by competitive polymerase chain reaction. Mycol. Res. 101: 1440-1444.

GARDES M. \& BRUNS T.D. (1993): ITS primers with enhanced specifity for basidiomycetes - application to the identification of mycorrizae and rusts. Molec. Ecol. 2: 113-118.

GARDES M. \& BRUNS T.D. (1996): Community structure of ectomycorrhizal fungi in a Pinus muricata forest: Above- and below-ground views. Canad. J. Bot. 74: 1572-1583. 
GARDES M., WHITE T.J., FORTIN J.A., BRUNS T.D. \& TAYLOR J.W. (1991): Identification of indigenous and introduced symbiotic fungi in ectomycorrhizae by amplification of nuclear and mitochondrial ribosomal DNA. Canad. J. Bot. 69: 180-190.

GiovanNETTI M., AZZOLIN1 D. \& CiTERNESI A.S. (1999): Anastomosis formation and nuclear and protoplasmic exchange in arbuscular mycorrhizal fungi. Appl. Environm. Microbiol. 65: 5571-5575.

GRAHAM J.H., HODGE N.C. \& MORTON J.B. (1995): Fatty acid methyl ester profiles for characterization of glomalean fungi and their endomycorrhizae. Appl. Environm. Microbiol. 61: 58-64.

Helgason T., DANiEll T.J., HUSBAND R., FitTer A.H. \& Young J.P.W. (1998): Ploughing up the wood-wide web? Nature 394: 431.

HELGASON T., FITTER A.H. \& YOUNG J.P.W. (1999): Molecular diversity of arbuscular mycorrhizal fungi colonising Hyacinthoides non-scripta (bluebell) in a seminatural woodland. Molec. Ecol. 8: 659-666.

HEgason T., MERRYWEATHER J.W., DENISON J., WILSON P., YOUNG J.P.W. \& FITTER A.H. (2002): Selectivity and functional diversity in arbuscular mycorrhizas of co-occurring fungi and plants from a temperate deciduous woodland. J. Ecol. 90: 371-384.

HORTON T.R. (2002): Molecular approaches to ectomycorrhizal diversity studies: Variation in ITS at a local scale. Pl. \& Soil 244: 29-39.

JANSA J., MOZAFAR A., ANKEN T., RUH R., SANDERS I.R. \& FROSSARD E. (2002): Diversity and structure of AMF communities as affected by tillage in a temperate soil. Mycorrhiza 12:225-234.

KJøLLER R. \& ROSENDAHL S. (2001): Molecular diversity of Glomalean (arbuscular mycorrhizal) fungi determined as distinct Glomus specific DNA sequences from roots of field grown peas. Mycol. Res. 105 : 1027-1032.

KOUFOPANOU V., BURT A. \& TAYLOR J.W. (1997): Concordance of gene genealogies reveals reproductive isolation in the pathogenic fungus Coccidioides immitis. Proc. Natl. Acad. Sci. USA 94: 5478-5482.

KUHN G., HIJRI M. \& SANDERS I.R. (2001): Evidence for the evolution of multiple genomes in arbuscular mycorrhizal fungi. Nature 414: 745-748.

LANFRANCO L., DELPERO M. \& BONFANTE P. (1999): Intrasporal variability of ribosomal sequences in the endomycorrhizal fungus Gigaspora margarita. Molec. Ecol. 8: 37-45.

LANFRANCO L., WYSS P., MARZACHI C. \& BONFANTE P. (1995): Generation of RAPD-PCR primers for the identification of isolates of Glomus mosseae, an arbuscular mycorrhizal fungus. Molec. Ecol. 4: 61-68.

Lloyd MacGilP S.A., Chambers S.M., DOdD J.C., FitTer A.H., WALKeR C. \& YouNG J.P.W. (1996): Diversity of the ribosomal internal transcribed spacers within and among isolates of Glomus mosseae and related mycorrhizal fungi. New Phytol. 133: 103-111.

MERRYWEATHER J. \& FITTER A. (1998): The arbuscular mycorrhizal fungi of Hyacinthoides non-scripta: I. Diversity of fungal taxa. New Phytol. 138: 117-129.

MORTON J.B. \& REDECKER D. (2001): Two new families of Glomales, Archaeosporaceae and Paraglomaceae, with two new genera Archaeospora and Paraglomus, based on concordant molecular and morphological characters. Mycologia 93: 181-195.

O'DONNELL K. (1992): Ribosomal DNA internal transcribed spacers are highly divergent in the phytopathogenic ascomycete Fusarium sambucinum (Gibberella pulicaris). Curr. Genet. 22: 213-220.

OEHL F. SiEVERDING E., INEICHEN K., MÄDER P., BOLlER T. \& WIEMKEN A. (2003): Impact of land use intensity on the species diversity of arbuscular mycorrhizal fungi in agroecosystems of Central Europe. Appl. Environm. Microbiol. 69: 2816-2824.

REDECKER D. (2000): Specific PCR primers to identify arbuscular mycorrhizal fungi within colonized roots. Mycorrhiza 10: 73-80.

REDECKER D., HIJRI M., DULIEU H. \& SANDERS I.R. (1999): Phylogenetic analysis of a dataset of fungal 5.8S rDNA sequences shows that highly divergent copies of internal transcribed spacers reported from Scutellospora castanea are of Ascomycete origin. Fung. Genet. Biol. 28: 238-244.

REDECKER D., MORTON J.B. \& BRUNS T.D. (2000): Ancestral lineages of arbuscular mycorrhizal fungi (Glomales). Molec. Phylogenet. Evol. 14: 276-284.

RODRIGUeZ A., DOUgall T., DODD J.C. \& CLAPP J.C. (2001): The large subunit ribosomal RNA genes of Entrophospora infrequens comprise sequences related to two different glomalean families. New Phytol. 152: 159-167. 
SAiki R.K., GElfand D.H., StOFfel S., SCharf S.J., HigUCHI R., HORN G.T., MUllis K.B. \& ERLich H.A. (1988): Primer-directed enzymatic amplification of DNA with a thermostable DNA polymerase. Science 239: 487-491.

SCHÜBLER A., GEHRIG H., SCHWARzoTt D. \& WALKER C. (2001): Analysis of partial Glomales SSU rRNA gene sequences: implications for primer design and phylogeny. Mycol. Research 105: 5-15.

SCHWARZOTT D., WALKER C. \& SCHÜBLER A. (2001): Glomus, the largest genus of the arbuscular mycorrhizal fungi (Glomales), is non-monophyletic. Molec. Phylogenet. Evol. 21: 190-197.

SIEVERDING E. \& TORO S. (1985): The genus Entrophospora in Colombia. In: GIANINAzZI-PEARSON V. \& Gianinazzi S. (eds.), Proceedings of the 1st European Symposium on Mycorrhizae, Dijon, France, INRA, Paris, pp. 621-626.

SIMON L., LALONDE M. \& BRUNS T.D. (1992): Specific amplification of 18 S fungal ribosomal genes from vesicular-arbuscular endomycorrhizal fungi colonizing roots. Appl. Environm. Microbiol. 58: 291-295.

SIMON L., LEVESQUE R.C. \& LALONDE M. (1993): Identification of endomycorrhizal fungi colonizing roots by fluorescent single-strand conformation polymorphism polymerase chain reaction. Appl. Environm. Microbiol. 59: 4211-4215.

SWOFFORD D.L. (2002): PAUP*. Phylogenetic analysis using parsimony ( ${ }^{*}$ and other methods). Sinauer, Sunderland.

TAYLOR J.W., JACOBSON D.J., KROKEN S., KASUGA T., GEISER D.M., HIBBETT D.S. \& FISHER M.C. (2000): Phylogenetic species recognition and species concepts in fungi. Fung. Genet. Biol. 31: 21-32.

VAN TUINEN D., JACQUOT E., ZHAO B., GOLLOTTE A. \& GIANINAZZI-PEARSON V. (1998): Characterization of root colonization profiles by a microcosm community of arbuscular mycorrhizal fungi using 25 rDNA-targeted nested PCR. Molec. Ecol. 7: 879-887.

WHITE T.J., BRUNS T., LEE S. \& TAYLOR J. (1990): Amplification and direct sequencing of fungal ribosomal RNA genes for phylogenetics. In: INNIS M.A., GELFAND D.H., SNINSKY J.J. \& WHITE T.J. (eds.), PCR protocols, a guide to methods and applications, Academic Press, San Diego, pp. 315-322.

Encl. Appendix, p. 124 


\section{APPENDIX}

\section{Methods}

\section{Root sampling}

Roots were washed from $1.5 \mathrm{~cm}$ by $10 \mathrm{~cm}$ cores taken from a trap culture, divided into $50 \mathrm{mg}$ aliquots in $1.5 \mathrm{ml}$ tubes and frozen at $-80^{\circ} \mathrm{C}$.

\section{DNA extraction}

Roots were ground in liquid nitrogen with pestle and mortar or with a pellet pestle within the $1.5 \mathrm{ml}$ tube. DNA was extracted from roots with a DNeasy Plant Mini Kit (Qiagen, Hilden, Germany) according to the manufacturer's instructions. DNA was eluted in one step in $30 \mu \mathrm{l}$ elution buffer. Purified DNA was diluted $1: 10$ and $1: 100$ and used as template for the first PCR of the nested procedure.

\section{Polymerase chain reaction}

PCR was performed in a nested procedure as described by REDECKER (2000) using Taq polymerase from GIBCO BRL/Invitrogen/Life Technologies (Basel, Switzerland) or Applied Biosystems (Foster City, USA) and $2 \mathrm{mM} \mathrm{MgCl}_{2}$. The first round of amplification was performed using primers NS5 and ITS4 (WHITE et al. 1990).

The success of this non-specific amplification was not routinely controlled by gel electrophoresis. PCR products were diluted $1: 100$ in TE and used as template in the second round: (a) (forward cocktail) ARCH1311, ACAU1661, LETC1670- ITS4i. (b) (reverse cocktail) ITS1F-GLOM5.8R,GIGA5.8R. In the second round of amplification, the primer ITS4i (TTGATATGCTTAAGTTCAGCG) was used instead of ITS4 to prevent PCR artifacts. It is a universal primer and nested a few bases within ITS4. The primer ACAU1661 (TGAGACTCTCGGATCGGG) is one base longer than ACAU1660 (REDECKER 2000) at the 3' end and therefore has improved specificity.

PCR products from the second round of nested PCR were run on agarose gels $(2 \%: 1 \%$ NuSieve/SeaKem, FMC, Rockland, ME, USA). The size of the PCR product gave first hints about the fungal group present in the sample. For example, a PCR product of $200 \mathrm{bp}$ with the reverse cocktail (primer GLOM5.8R) is an indication for Glomus group A, a 1000 bp fragment in the forward reaction (ARCH1311 primer) indicates Archaeospora/Paraglomus. Positive samples were amplified again using the PCR products of the first round of amplification as a template and the following primer combinations: ARCH1311-ITS4i, GLOM1310-ITS4i, ACAU1661-ITS4i, LETC1670-ITS4i, ITS1F-GIGA5.8R (REDECKER 2000). Some AMF from Glomus group A were found to have mismatches in the GLOM1310 priming site. In these cases, the combination NS5-GLOM5.8R proved to be useful (BIDARTONDO et al. 2002).

\section{Cloning and sequencing}

PCR products were cloned into a pGEM-T vector (Promega/Catalys, Wallisellen, Switzerland). Inserts were reamplified, digested with $\mathrm{Hinfl}$ and $\mathrm{MboI}$ and run on agarose gels. Representatives of each restriction type were then sequenced in both directions. PCR products to be sequenced were purified with QIAquick (Quiagen). A BigDye Terminator Cycle Sequencing Kit (ABI, Foster City, CA, USA) was used for labeling. Samples were run on an ABI 310 capillary sequencer. Sequences were deposited in the EMBL database under the accession numbers AJ515173-AJ515176.

\section{Sequence analysis}

Sequences were manually aligned to previously published sequences and phylogenetically analysed in PAUP*4b10 (SWOFFORD 2002). Five different ITS alignments were made, one for the target taxon group of each specific primer.

Sequences in the databases showing evidence of non-glomalean origin were excluded. Some ITS sequences from "Glomus intraradices" were grouping with the Glomus etunicatum group (Glomus group B, nomenclature after SCHÜBLER et al. 2001) and were therefore not included in the alignment for Glomus group A (G. intraradices/G. mosseae). ITS sequences from G. fasciculatum (LLOYD MACGILP et al. 1996) that are in strong disagreement with $18 \mathrm{~S}$ phylogeny (SCHWARzOTT et al. 2001) and morphologically-based taxonomy were also excluded. 